\title{
ALTERNATIVE FILLERS FOR USE IN SLURRY SEAL
}

\section{N. OIKONOMOU ${ }^{1, *}$ P. ESKIOGLOU ${ }^{2}$}

Received: 04/04/06

Accepted: 19/12/06
${ }^{1}$ Laboratory of Building Materials, Department of Civil Engineering Aristotle University of Thessaloniki, 54 124, Thessaloniki, Greece ${ }^{2}$ Laboratory of Mechanical Sciences and Topography Department of Forestry and Natural Environment Aristotle University of Thessaloniki, 54124 Thessaloniki, Greece

*to whom all correspondence should be addressed: e-mail: ikonomou@civil.auth.gr

\section{ABSTRACT}

Slurry seal is applied for low-cost paving and surface maintenance. The principal materials used to create slurry seal are aggregates, asphalt emulsion, water and fillers like Portland cement (mainly), lime and other materials.

This paper presents the use of alternative fillers instead of expensive and high consumed energy cement. These fillers are by-products and their increased deposits create a serious environmental problem. Fly ash, ladle furnace slag, cement kiln dust, marble dust were tested as fillers in slurry seal and results showed that they can be used producing slurry seal according to specifications. Mixing time, consistency, set time, cohesion, wet stripping, wet track abrasion and loaded wheel were the tests for checking of the characteristics of designed slurry seals.

The use of these by-products will minimize their deposits and in a parallel manner will decrease the use of corresponding amount of cement saving raw materials and energy consumed for its production.

KEYWORDS Index: Slurry seal, road maintenance, fillers, recycling, alternative materials

\section{INTRODUCTION}

Slurry seal [1] is a mixture of aggregates, asphalt emulsion, water and fillers which are mixed together according to a laboratory, design mix formula [1]. Slurry seal is applied to an existing pavement surface by means of a spreader box linked to the slurry mixing unit (figure 1).

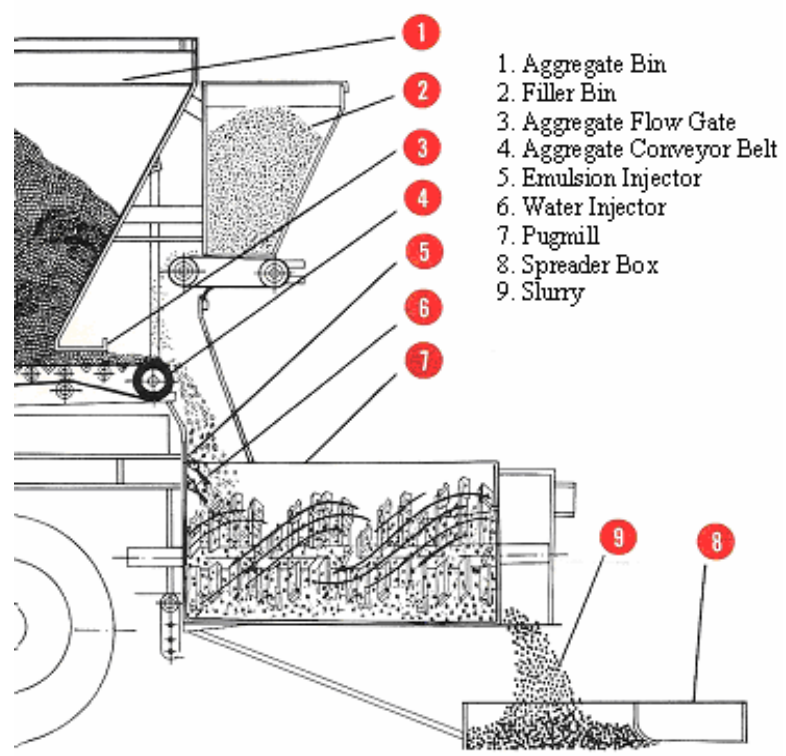

Figure 1. Application of slurry seal 
Slurry seal is a well known surface maintenance method because it is cost effective, extends life of pavement, is quickly applied, and improves road handling characteristics.

In Greece, slurry seal was introduced in 1984 as a skid resistance restoration technique [3]. Until today more than 10 millions square meters have been laid on Greek flexible roads and runways surfaces with slurry seal and microsurfacing, a slurry seal of high quality.

Portland cement is normally used in quantities of $1-3 \%$ of aggregates in slurry seal. It is primarily used to improve the homogeneity of slurry seal. Since cement is an expensive and high consumed energy material for slurry seal production, this paper presents the use of alternative fillers in slurry seal. By-products fillers exist in Greece from various manufacturing activities. These materials are normally deposited in Greece creating a huge environmental problem.

The alternative fillers tested in this research were:

- Fly ash. It is a by-product from Greek coal-fired electric power generation plants (coal combustion product). Its annual production in Greece is more than 12 millions tns and from this amount only $6-8 \%$ is used for some special uses(in cement and concrete production) but the rest is deposited increasing every year this problem.

- Laddle furnace slag. This slag is produced from the second phase of manufacturing of steel and its annual production from steel manufacturer in Northern Greece is 30000tns approximately.

- Cement kiln dust. This filler is collected from electric filters during the production of Portland cement and it is mainly reused in cement production.

- Marble dust. It is produced as mixture with water which is used for cutting of marbles. Only in Northern Greece more than 5000 tns are produced annually from marble treatment factories.

Steel slag has been used as alternative aggregate $[4,5]$ giving improved performance of slurry seal and fly ash as alternative filler in microsurfacing [6], giving specific advantages.

In this paper a wide range of sub-products has been examined is slurry seal in order to decrease cement use and their deposits. Results from this research showed that the use of these by-products gave slurry seal complying with specifications.

\section{EXPERIMENTAL STUDY}

\subsection{Materials}

\section{a. Aggregate}

The aggregate used was produced from crushing a diabase rock. The characteristics of the aggregate are showed in Table 1.

Table 1. Characteristics of aggregate.

\begin{tabular}{lc}
\hline \multicolumn{1}{c}{ Test } & Result \\
\hline Gradation & Figure 1 \\
Sand equivalent, \% & 88 \\
Methylene blue value & 0,1 \\
Soundness(Na ${ }_{2}$ SO4), \% & 8,5 \\
Bulk specific gravity(fine), g cm & -3 \\
Bulk specific gravity(coarse), g cm & 2,85 \\
Water absorption(fine), \% & 2,78 \\
Water absorption(coarse), \% & 1,2 \\
Abrasion (L.A.), \% & 0,7 \\
Micro Deval, \% & 22 \\
Polished Stone Value & 12 \\
\hline
\end{tabular}

The gradation curve of used aggregate is showed in Figure 2. 


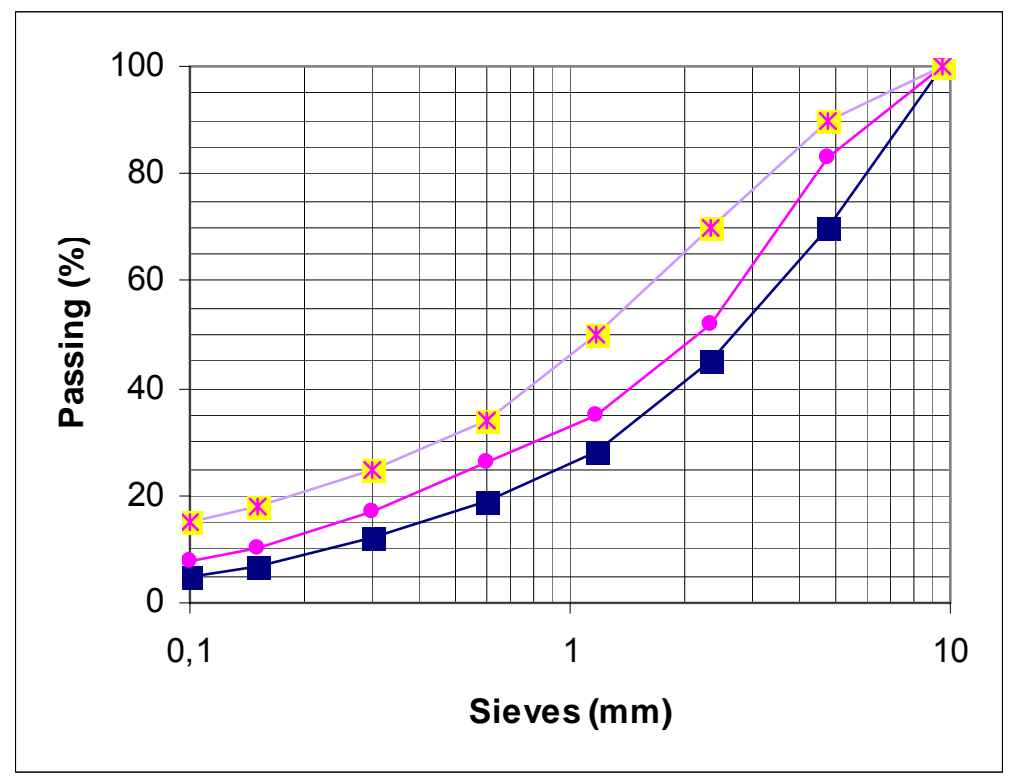

Figure 2. Gradation curve $(\bullet)$ of used aggregate (ASTM D-3910, Type III, [7])

b. Asphalt emulsion

$\mathrm{X}$ : upper limit, $\mathbf{a}$ : lower limit

Asphalt emulsion was supplied by BITOUMINA S.A., Thessaloniki and was tested according to ASTM D2397 [8] as a quick set emulsion. Its characteristics are showed in Table 2.

Table 2. Characteristics of asphalt emulsion

\begin{tabular}{ll}
\hline Test & Results \\
\hline$\bullet \quad$ Test on emulsion & \\
\hline residue by distillation & 62 \\
Viscosity, S.F. $\left(25^{\circ} \mathrm{C}\right), \mathrm{s}$ & 27 \\
particle charge & possitive $(\mathrm{pH} 2,8)$ \\
\hline Test on residue & \\
Penetration $\left(25^{\circ} \mathrm{C}, 100 \mathrm{~g}, 5 \mathrm{sec}\right), 0.1 \mathrm{~mm}$ & 55 \\
\hline
\end{tabular}

c. Fillers (95-100\% passing No $200 / 0.075 \mathrm{~mm}$ sieve)

Fillers used in this research were:

- Ordinary Portland cement (OPC) which was supplied by cement factory TITAN S.A., Thessaloniki.

- Fly ash which was a high calcium one (HCFA) with a $4.2 \%$ of free $\mathrm{CaO}$. It was from the electric power plant in Ptolemais, Northern Greece.

- Laddle furnace slag (LFS) was supplied by the steel factory SIDENOR S.A., Thessaloniki.

- Cement kiln dust (CKD) with a $3.8 \%$ of free $\mathrm{CaO}$ was supplied by TITAN S.A., Thessaloniki.

- Marble dust (MD) was supplied by the marble factory ZLAKIOS S.A.,Thessaloniki.

The composition of used fillers is showed in Table 3.

\subsection{Mix design}

The mix design was performed according to ASTM [7] and ISSA [2]. The components of the slurry seal mixture per $100 \mathrm{~g}$ of aggregate is showed in Table 4.

\subsection{Testing}

Five slurry seal mixtures were tested using all available fillers according to specifications. The mixing temperature was $25 \pm 2^{\circ} \mathrm{C}$ and the relative humidity was $50 \pm 5^{\circ} \mathrm{C}$. 
Table 3. Composition of used fillers.

\begin{tabular}{|l|c|c|c|c|l|}
\hline \multicolumn{1}{|c|}{ Filler } & OPC & HCFA & LFS & CKD & MD \\
\hline $\mathrm{SiO}_{2}$ & 22.8 & 33.5 & 23.2 & 12.8 & \\
\hline $\mathrm{CaO}$ & 60.3 & 38.1 & 60.9 & 44.2 & \\
\hline $\mathrm{FeO}$ & 2.6 & 4.3 & 0.3 & 1.8 & \\
\hline $\mathrm{Al}_{2} \mathrm{O}_{3}$ & 6.3 & 13.8 & 3.0 & 4.7 & \\
\hline $\mathrm{MgO}$ & 2.1 & 3.6 & 5.9 & 0.9 & \\
\hline $\mathrm{Na}_{2} \mathrm{O}$ & 0.4 & 0.7 & 0.06 & 0.4 & \\
\hline $\mathrm{K}_{2} \mathrm{O}$ & 1.0 & 1.1 & 0.01 & 1.1 & \\
\hline $\mathrm{MnO}$ & & & 0.50 & & \\
\hline $\mathrm{S}$ & & & 0.30 & & \\
\hline $\mathrm{CaCO}_{3}$ & & & & & 87.2 \\
\hline $\mathrm{MgCO}_{3}$ & & & & & 10.4 \\
\hline
\end{tabular}

Table 4. Basic design of slurry seal mixture.

\begin{tabular}{lr}
\hline Material & Parts \\
\hline Aggregate & 100 \\
Asphalt emulsion & 10 \\
Filler & 2 \\
Water & 8 \\
\hline
\end{tabular}

\section{RESULTS AND DISCUSSION}

The results obtained from the use of alternative fillers in slurry seal are showed in Table 6. As it can be seen all fillers gave acceptable under specification slurry seal [5.8]. Furthermore, the addition of marble dust (MD) which is a non-pozzolanic material gave a material with higher stiffness (low flow in core consistency test, low mixing time). All the other alternative fillers (HCFA, LFS, CKD) which have pozzolanic properties especially in this low gradation $(<200 \mu \mathrm{m})$ showed more interesting results and in some cases (HCFA, LFS) better than OPC use (e.g. in cohesion test and WTAT for longer time testing.

Different set times showed that slurry seal with alternative fillers can apply in shorten or longer times according to application design. All filler gave satisfactory results concerning wet stripping (>95\% coating) and excess asphalt by Loaded Wheel Tester $\left(<430 \mathrm{~g} \mathrm{~m}^{-2}\right)$

\section{CONCLUSIONS}

Slurry seal is applied with great success in Greece during the last twenty years for road maintenance and improving surface characteristics. Portland cement participates in slurry seal as filler for better adhesion and mixing purposes. In this paper four alternatives fillers were used in order to substitute cement in the production of slurry seal. The results showed that any of these fillers can be used instead of cement producing slurry seal complying with specifications. The use of these alternative fillers result in decreasing of their deposits in the region of Northern Greece and of the consumption of cement, which is a construction material with low environmental profile(from natural resources and energy point of view). 
Table 5. Tests on slurry seal.

\begin{tabular}{lccccccc}
\hline $\begin{array}{l}\text { Used filler(2\% on aggregate) } \\
\text { Test }\end{array}$ & OPC & HCFA & LFS & CKD & MD & ASTM[5] & ISSA[8] \\
\hline Mixing time, sec & 134 & 125 & 122 & 137 & 108 & $60-180$ & $>120$ \\
\hline Cone consistency, cm & 2.7 & 2.3 & 2.8 & 2.6 & 2.1 & $2-3$ & \\
\hline Set time, sec & 175 & 143 & 151 & 196 & 228 & $<1 \mathrm{~h}$ & \\
\hline Cohesion, $30 \mathrm{~min}, \mathrm{~kg} \mathrm{~cm}$ & 17 & 14 & 15 & 15 & 13 & & $>12$ \\
\hline Cohesion, 60min, $\mathrm{kg} \mathrm{cm}^{-2}$ & 25 & 26 & 28 & 23 & 22 & & $>20$ \\
\hline WTAT, $1{\mathrm{~h} \mathrm{soak,} \mathrm{g} \mathrm{m}^{-2}}^{\text {WTAT, 6d soak, } \mathrm{g} \mathrm{m}^{-2}}$ & 312 & 321 & 336 & 314 & 362 & $<807$ & $<538$ \\
\hline Wet stripping, \% & 540 & 506 & 512 & 532 & 544 & & $<807$ \\
\hline Excess asphalt by CWT, $\mathrm{g} \mathrm{m}^{-2}$ & $>95$ & $>95$ & $>95$ & $>95$ & $>95$ & & $>90$ \\
\hline OPC: Ording Pon & 429 & 382 & 416 & 371 & & $<538$ \\
\hline
\end{tabular}

OPC: Ordinary Portland Cement, HCFA: High Calcium Fly Ash, LFS: Laddle Furnace Slag, CKD: Cement Kiln Dust, MD: Marble Dust

\section{REFERENCES}

1. International Slurry Surfacing Association, Annapolis,(ISSA), USA, http://www.slurry.org

2. ISSA (2005) Recommended Performance Guidelines for Emulsified Asphalt, Slurry Seal, A105.

3. A.F. Nikolaides (1999) Microsurfacing for the maintenance of Athens airport main runway, Proceedings $3^{\text {rd }}$ European Symposium on Performance and Durability of Bituminous Materials and Hydraulic Stabilized Composites,133-143, Leeds.

4. Khan M.I., Wohhab Al-Abdul H.I. (1998) Improving slurry seal performance in Eastern Saudi Arabia using steel slag, Construction and Building Materials, 12, 195-201.

5. N.Oikonomou, P. Eskioglou (2005) Use of Furnace Steel Slag in construction of skid resistant microsurfacing, Proceedings of the 1rst Conference for the Utilization of Industrial By products in Building Construction, Thessaloniki, Greece, 439-447.

6. Nikolaides A., Oikonomou N. (2000) The use of fly ash as a substitute of cement in microsurfacing, Waskon 2000, International Conference on the Science and Engineering of Recycling for Environmental Protection, Harrogate, U.K.

7. ASTM D 3910 (1996) Design, Testing and Construction of Slurry Seal, Annual Book of ASTM Standards, Section 4, Construction, Vol.04.03, Road and Paving Materials.

8. ASTM D 2397 (1996) Standard Specification for Cationic Emulsified Asphalt, Annual Book of ASTM Standards, Section 4, Construction, Vol.04.03, Road and Paving Materials. 